\title{
CONSIDERATIONS ON THE CONTRIBUTIONS OF JUDO TO THE DEVELOPMENT AND IMPROVEMENT OF MOTOR QUALITIES AND SKILLS PERTAINING TO CLOSE COMBAT
}

\author{
Robert STĂNCIULESCU \\ "Nicolae Bălcescu" Land Forces Academy, Sibiu, Romania \\ rstanciulescu@armyacademy.ro
}

\begin{abstract}
The growing complexity of the physical and mental demands of the modern battlefield imposes an intensive program of instruction and education of the military meant to improve their performances. Through its specific training methods and means, judo ensures a complex set of motor and utilitarian-applicative skills and abilities, as well as a wide capacity of focusing attention and will, necessary in the fighter's adjustment to the rapid and unexpected changes which appear during the combat.
\end{abstract}

Keywords: Fighter, opponent, actions, training, motor qualities

\section{Introduction}

Military actions carried out under everdiversified conditions, the rapid change of the forms of fighting, and the need for action in the depth of the enemy's device are some of the characteristic features of the modern combat that require increasingly complex training of the fighters. The decisive factor in combating the harmful effects of the increasingly complex missions on the physique and psyche of the fighters is the theoretical and practical training, the training to master the emotional experiences, the strengthening of the will and the formation of a winning mentality. The fighters have to identify ways to survive in extreme conditions and to cope with all the challenges of this type of war, an essential element of success in the combat being an extraordinary physical and psychic potential. Physical and psychological development that is systematic and continuous, increases the ability to act as it strengthens the muscles, increase joint elasticity, improve reflexes, and provide physical and moral balance. The effect of physical exercise is manifested by the ability of the fighter to act spontaneously and efficiently, not only by simplistic learning of a combat method, but also by the development of a sense of skill to intuitively synchronize his own actions in each situation, so that action becomes identical to the mission to be accomplished. Analyzing the impact of the battlefield has on the physique and psyche, we find that the fighter must have a body that is resistant to prolonged physical effort, have the necessary force to carry out combat activities where fire can not be used individually and give proof of skill and mobility, thus enhancing the ability to adapt to unpredictable situations occurring during the combat.[1] Considered as a process of adaptation of the body to the efforts imposed by the combat, by developing at 
higher parameters of force and resistance, by providing some indices of speed and skill manifestation, or through the development of basic and applicative motor skills, physical education must provide the fighter with the ability to adapt permanently to changes in the battlefield. The manifestation of basic motor skills, speed, skill, strength and endurance are found in combat, in the application of attack and defense techniques in real-time confrontations, and contribute substantially to self-assurance, calmness or self-control, and ensuring a high morale. The result of a well-designed and efficient training is found in the formation of well-motivated, confident fighters with great power of concentration and a well-developed and resisting body.

As a pillar of the training process, physical education includes the disciplines with contributions to the formation and development of the physical and psychological potential necessary for the success in the combat, judo, the study discipline which mainly aims at the formation and improvement of skills and competencies with applicability in the complex actions of close combat, of distraction and anti-distraction, as well as in the combat in which individual firearm can not be used.

\section{Judo - fighting sport with special implications in the training of fighters} 2.1. The benefits of judo in close combat

Really contributing to the increase of combatants fighting by the development of basic motor skills, psychic qualities of coordination and self-indulgence in front of the factors that cause pain and fear, courage and confidence in their own forces, judo forms skills and develops absolute qualities required to carry out the actions successfully, isolated or in group, under any geoclimatic conditions [2]. Thus forming skills to attack, block and counter-act barehanded or with the individual weapons in the equipment is also aimed at training the skills of fighting against several armed opponents. The discipline with wellperfected and executed processes has multiple effects on the ability to fight; judo actually contributes to the formation of a skilled human resource capable of effectively managing close combat actions. Judo is one of the most dynamic sports disciplines that, through its psychomotor and somatic qualities, contribute to the formation of the personality of the practitioners.[3] Judo's evolution finds its origin in Japan, where centuries ago it was practiced by samurai in the form of the traditional jiu-jitsu which means the art of suppleness and which is a method of attack and defense characterized by the use of various joint contractions actions and strikes on the vital points of the human body. For many centuries jiu-jitsu has been a means of attack and personal defense, allowing the samurai to fight even against an armed opponent. According to the origin of the jiu-jitsu, it appears from the existing documents that it appeared in the second half of the 16th century and was perfected by JIGORO KANO who, being initiated in the mystery of this sport at the most famous schools in the world, after having eliminated the dangerous forms in the jiujitsu content, has organized and completed the technical procedures providing the basis of a new style of combat. In 1882 Professor Jigoro Kano transformed the word jitsu which means art in do which means the path or method and formed judo, which in time gained more and more followers and later on received an official nature. After 1940 , this sport spread rapidly across the globe, and in 1951 the first European judo championship was held in Paris. In 1964, judo became an Olympic sport, gaining a universal character. In Romania, judo was introduced in 1928 at the National Office of Physical Education. Judo performance has become a current priority, trying to solve training problems through new methods [4]. In this context, the analysis of the current combat has demonstrated the essential role of the specific physical capacity considered, not without reason, the core of 
performance. Studies on the biomechanics of the execution of judo determined the emergence of new shapes and methods of training with a more specific character, currently representing an essential concern in achieving performance.

\subsection{Judo procedures used in the training of fighters}

The judo procedures used in the training of fighters are chosen to be adapted and used in all the complex and difficult situations that can be encountered on the battlefield and which the fighter needs to prove spontaneity and improvisation in order to be successful: falls, breakings, reaps, projections, holds, chokes and joint locks.

The grips (KUMI-KATA) greatly condition the way of judging and perfecting the judo procedures and are the following: A correct grip determines the success of the process, so it is essential that during the training, one should insist especially on the automation of the procedure. The main types of gripping are: LAPEL-SLEEVE, LAPEL-LAPEL, REAR LAPEL-SLEEVE, SLEEVE-BACK, LAPEL-BACK, but also other grips, depending on the particularities of the performed procedures, or by the ingenuity of the practitioners.

The fundamental position (SHIZENHONTAI) is essential for the combat and performance.

Within the basic position, the legs are distanced from the shoulders, slightly flexed, and the body has a natural position, almost vertical. The fundamental position can be adapted to the specifics of the situations occurring during the combat and greatly conditions the outcome of the combat.

Breakings (KUZUSHI) play an extremely important role in the combat. They are done at the same time, and the success of the procedure requires a very good synchronization between the body segments. If done correctly, the opponent does not notice the fighter's intentions and the premises are created for the execution of some combat procedures that can ensure success.
MOVEMENTS may be forward, backward, laterally to the left, laterally to the right. They can also be executed in the same direction as the opponent moves. Doing them properly is essential because the fighter can lose balance if the execution is not correct. These must be executed with great skill, because many stages of the combat depend on them.

Falls (UKEMI). They should be learned and improved before learning the actual processes and greatly condition the results.[5] Their role is also found in the psychological training of the fighter, giving him the confidence and control in combat. Both the defense and the counterattack depend greatly on the way they are performed and used. Reaps and throws (NAGE-WAZA). The main throwing procedures used are:

- DE-ASHI-BARAI (forward foot sweep)

- HIZA-GURUMA (knee wheel)

- SASAE-TSURI-KUMI-ASHI (supporting foot lift-pull throw)

- O-SOTO-GARI (large outer reap)

- O-UKI-GARI (large inner reap)

Their role is extremely important because it is the essence in close combat, ensuring success or failure and finally the outcome of the military action.

Holds (NE WAZA) which are presented in several forms and which also have an essential role since taking the opponent out of the combat is done by immobilization. These are:

- KESA GATAME (scarf hold)

- KAMI-SIHO-GATAME (top fourcorner hold)

- HADAKA-JIME (naked strangle)

- OTEN-JIME (rolling strangle)

- UDE-HISHIGI-JUJI-GATAME (cross lock)

- UDE-HISIGI-HIZA-GATAME (knee lock)

The training and development of judo skills and abilities, performing a perfect fighting technique, the tactical and psychological training specific to this combat sport are elements that contribute essentially to the 
process of training and developing the skills and abilities of combat for the military.

\section{Conclusions}

With their particularly complex demands on the human body, combat sports lead to positive, multiple and unique effects in developing motor skills, and judo, through specific contents, methods and means is a useful and effective way to meet the formative goals.
The optimization of the level of training of the fighter through specific means of judo, a very useful and current solution, offers practical solutions and makes new openings, as a result of the concern to identify the formative needs in the context of the current Romanian Armed Forces mission and to facilitate the physical adaptation of the fighter to the new demands imposed by the modern battlefield.

\section{References}

[1] FLOCA, M., Forţele de elită ale lumii, București, Editura Militară, 1999.

[2] ROBERT STANCIULESCU,Sporturi de lupta in educatia fizica militara ,Editura Academiei Fortelor Terestre Nicolae Balcescu SIBIU,2008

[3] EPURAN, M., HORGHIDAN, V., Psihologia educaţiei fizice, Bucureşti, A.N.E.F.S., 1994.

[4] HANTĂU, I., Teoria şi metodica judoului, Bucureşti, 2005.,

[5] HANTĂU, I., Manual de judo, Bucureşti, Editura Didactică şi Pedagogică, 1996 